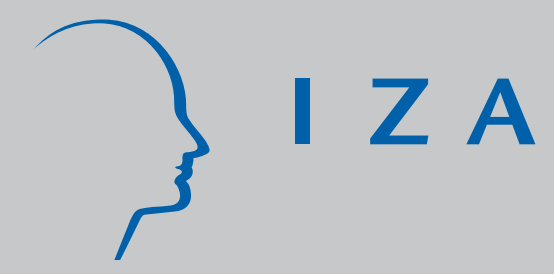

IZA DP No. 4088

The Growth of Participant Direction in Defined Contribution Plans

William E. Even

David A. Macpherson

March 2009 


\title{
The Growth of Participant Direction in Defined Contribution Plans
}

\author{
William E. Even \\ Miami University \\ and IZA \\ David A. Macpherson \\ Florida State University \\ and IZA
}

Discussion Paper No. 4088

March 2009

\author{
IZA \\ P.O. Box 7240 \\ 53072 Bonn \\ Germany \\ Phone: $+49-228-3894-0$ \\ Fax: +49-228-3894-180 \\ E-mail: iza@iza.org
}

\begin{abstract}
Any opinions expressed here are those of the author(s) and not those of IZA. Research published in this series may include views on policy, but the institute itself takes no institutional policy positions.

The Institute for the Study of Labor (IZA) in Bonn is a local and virtual international research center and a place of communication between science, politics and business. IZA is an independent nonprofit organization supported by Deutsche Post Foundation. The center is associated with the University of Bonn and offers a stimulating research environment through its international network, workshops and conferences, data service, project support, research visits and doctoral program. IZA engages in (i) original and internationally competitive research in all fields of labor economics, (ii) development of policy concepts, and (iii) dissemination of research results and concepts to the interested public.
\end{abstract}

IZA Discussion Papers often represent preliminary work and are circulated to encourage discussion. Citation of such a paper should account for its provisional character. A revised version may be available directly from the author. 
IZA Discussion Paper No. 4088

March 2009

\section{ABSTRACT}

\section{The Growth of Participant Direction in Defined Contribution Plans}

Since 1990, most pension plans have shifted the responsibility for directing pension assets to the employee. This study summarizes some of the possible explanations for this rapid shift toward participant direction and uses IRS Form 5500 data to investigate the effect of worker and plan characteristics on the likelihood of making a switch. The study also estimates the effect of a switch to participant direction on employee contribution and asset allocation behavior. The analysis reveals that collective bargaining and pension investments in employer stock reduce the chance of a switch to participant direction, whereas below average return performance increases the chance. Also, a switch to participant direction increases employee contributions to the pension and reduces the share of assets invested in employer securities.

JEL Classification: J32

Keywords: participant direction, pensions, employer stock

Corresponding author:

David A. Macpherson

Department of Economics

Florida State University

Tallahassee, FL 32306

USA

E-mail: dmacpherson@fsu.edu 


\section{Introduction.}

Twenty years ago, the vast majority of defined contribution pension plans in the United States were managed by trustees on behalf of the plan participants. However, there has been a complete reversal of this in the past 20 years. Between 1988 and 2005, the percentage of defined contribution (DC) participants who manage some or all of the assets in their pension rose from 15 to 86 percent.

This rapid shift in the responsibility for investing the pension contributions raises several questions. First, what led firms to hand control over to the participants? Second, what are the consequences of this shift in responsibility for important pension metrics like contribution levels, asset allocation, and rate of return?

While there has been some research on the question of how participant direction affects asset allocation and contribution levels, there has been virtually no research on why firms switched to participant direction. Our study achieves two objectives. First, using data from IRS Form 5500 filings between 1988 and 2005, we provide insights into the types of worker and plan characteristics that influence a firm's decision to switch to participant direction. Second, we exploit panel features of our data to revisit some of the questions addressed in earlier studies with respect to the impact of participant direction on contributions and asset management.

\section{Background.}

The research on participant direction of DC plans is relatively limited. One line of research investigates how a shift to participant direction affects asset allocation decisions and contribution levels. Papke (1998, 2003a) finds that participant direction increases the share of assets invested in equities. Weisbenner (2002) finds that participant direction increases worker 
equity holdings outside of their pension plans, perhaps because workers who direct their pension plan invest in financial knowledge. Papke (2003a, b) also finds evidence that participant direction increases employee participation and contribution rates in pension plans. These findings have obvious implications for the impact of the growth in participant direction on future retirement income security.

Another line of inquiry examines whether workers have sufficient financial knowledge to properly manage their pension funds and finds some evidence of poor decision making by workers. For example, when an employer makes matching contributions in the form of employer stock, some employees make poor diversification decisions by investing their own contributions in the same stock. ${ }^{1}$ Yet other employees may pursue a naive " $1 / \mathrm{n}$ ” diversification strategy and invest equal shares in all the investment options offered by the pension plan. ${ }^{2}$ Other research suggests that workers rarely reallocate their pension investments and may overreact to recent stock performance when making investment decisions. ${ }^{3}$

An important question that has not been addressed in the existing literature is why firms have switched to participant direction. While there has been some speculation as to the underlying causes, we are unaware of any empirical work that focuses on this question specifically. To guide the discussion, we first delineate some of the costs and benefits of a switch to participant direction and then describe several factors that may have caused the net benefits of participant directed plans to rise.

\footnotetext{
${ }^{1}$ See Benartzi (2001), Liang and Weisbrenner (2002), and Brown et al. (2004).

${ }^{2}$ Benartzi and Thaler (2001) and Agnew (2001) both find evidence of 1/n investment behavior. Huberman and Jiang, (2004) find that investors do not exhibit 1/n behavior.

${ }^{3}$ Benartzi (2001) and Sengmuller (2002) discuss the effect of recent stock performance on investment behavior; Samuelson and Zechkhauser (1988) and Americks and Zeldes (2001) show that portfolio rebalancing is infrequent.
} 
There are several potential benefits to giving employees control over the investment of pension assets. First, it allows employees to tailor their investments to their own risk preferences and adjust the mix of assets for life-cycle considerations. To the extent that the employees prefer this over a centrally managed account, their valuation of the pension rises and the firm can pay their workers lower wages and still remain competitive in the labor market. Second, if the firm satisfies certain requirements (described below), a switch to participant direction can protect the employer from charges of fiduciary neglect if the pension performs poorly.

A switch to participant direction is not without its shortcomings. First, individual accounts are more expensive to administer than group accounts. This could be especially important for pensions where the typical account balance is small since some of the administrative expenses (e.g. record keeping) are fixed per participant and could have substantial negative effects on the rate of return. In fact, the administrative expenses associated with individual accounts have been highlighted as one of the potential shortcomings of Social Security privatization. ${ }^{4}$

A second potential shortcoming of a switch to participant direction is that participants may lack the financial sophistication required to adequately manage their own pension funds and actually prefer that the funds be managed by a professional.

Finally, if employers make contributions of their own stock to the pension plan in an attempt to align employee incentives with firm performance, or to help reduce the chances of a hostile take-over, a shift toward participant direction may mean that employees may shed the employer stock. While this may improve the diversification properties of the pension portfolio,

\footnotetext{
${ }^{4}$ See, for example, Page (2004).
} 
there could be offsetting losses to the employer in terms of higher agency costs or the increased threat of a take-over.

With the above benefits and costs in mind, we propose two explanations for the growth in participant direction: (1) regulatory changes that allowed employers to insulate themselves from fiduciary liability if employees made poor investment decisions; and (2) technological change that reduced the additional administrative cost associated with management of individual accounts.

Under section 404(a) of the Employee Retirement and Income Security Act (ERISA) passed in 1974, the pension sponsor (employer) is given the obligation to prudently select and monitor pension offerings to ensure a diverse selection of investment alternatives and can be held liable for the investment decisions of employees. Section 404(c) of ERISA, finalized in 1992, allows employers to transfer legal responsibility for losses resulting from a participant's exercise of control over his or her account if the plan sponsor meets certain conditions. To receive protection, the pension must (1) offer a broad range of investment alternatives; (2) give participants sufficient control over asset allocation decisions (i.e. an ability to frequently reallocate); and (3) distribute sufficient information about the investment choices (i.e. provide prospectuses for all the investment alternatives). These regulations reduced the uncertainty regarding employer liability for participant decisions and, as suggested by Papke (2003a, b), may have contributed to employers' increased willingness to give employees’ control over their pension assets.

Technological advances may have provided additional stimulus for participant direction [Kaplan 2003]. Advances in computing technology made daily trading and valuation less costly and made it easier for employers to comply with 404(c) requirements. The concurrent growth of 
mutual funds that provided low cost methods for diversifying, even with small asset holdings, provided yet another reason to shift towards participant direction.

While clarification of section 404(c) requirements and technological advances may have contributed to the rise in participant direction, the extent to which employees in a particular plan pressure the firm for a switch to participant direction should depend upon the financial sophistication of the employees and how well the plan performed relative to the market. A more financially sophisticated group of workers would be more likely to want to control their own investments while others may prefer to have a trustee manage the funds for them. At the same time, if a pension has underperformed relative to the market, workers may become unhappy with the returns and pressure the firm to give them control of the investment decisions. For example, Elswick (2002) describes the pressure on unionized plans to convert to participant direction during the 1990s. The trustees in a typical union plan allocated nearly $75 \%$ of assets in fixed income options and $25 \%$ in equities and were earning single-digit returns. The investment allocation was described as a good fit for retirees and conservatively-minded investors, but many workers were disappointed with the returns given the performance of their own private investments.

\section{Data and Trends.}

Our study relies on IRS Form 5500 filings for pension plans from 1988 through 2005. The research data files that we use include the universe of filings for plans with 100 or more participants, and a 5 percent sample of plans with less than 100 participants. We restrict our sample to the universe of DC plans, but keep track of whether the firm also offers a DB plan. 
Figure 1 presents the percentage of DC plans and participants with participant direction for the years 1988 through 2005. A plan is classified as participant directed if there are individual accounts and employees can manage at least some (but not necessarily all) of the assets. $^{5}$ The increase in participant direction is dramatic. Between 1988 and 2005, the percentage of plans with participant direction rose from 10 to 67 percent, and the percentage of

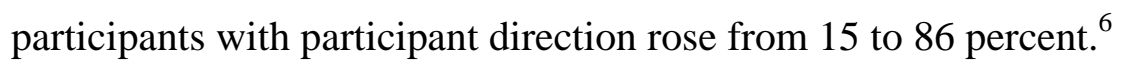

The growth of the 401(k) plan as a type of DC plan may have contributed to the growth of participant direction. If a DC plan has a 401(k) feature, employees can contribute pre-tax dollars into the pension and they typically have control over their own contribution levels. Without the 401(k) feature, employee contributions are after-tax dollars. If employers are more willing to give employees control over assets when they are contributing their "own money", the growth of the 401(k) plan may have contributed to the growth of participant direction.

Figure 2 provides some evidence on whether the growth of the 401(k) plan can account for the rapid growth in participant direction. While it is clear that DC plans are more likely to offer participant direction when there is a 401(k) feature, there has been rapid growth in participant direction regardless of whether the plan included the 401(k) option.

The growth in participant direction could be explained by two distinct phenomena: First, existing pension plans could be switching from centrally managed funds to participant directed accounts. Second, start up plans could be participant directed and/or plans that terminated may have been centrally managed. To determine the relevant importance of these two phenomena,

\footnotetext{
${ }^{5}$ According to the Form 5500 instructions prior to 1999, a plan should indicate that it is participant directed if it "provides for individual accounts and permits a participant or beneficiary to exercise independent control over the assets in his or her account." Starting in 1999, the Form 5500 provides 3 separate categories indicating whether the participant controls none, some, or all of the assets. Beyond 1999, we classify the latter two categories as participant directed plans.

${ }^{6}$ These estimates are weighted to reflect the fact that the small plans are a 5 percent sample.
} 
we calculate the percentage of plan participants with participant direction for plans started prior to 1988 versus those started 1988 or later. The results, presented in figure 3, illustrate that the plans started in 1988 or later are slightly more likely to be participant directed than those that existed prior to 1988. Nevertheless, even among the plans that existed prior to 1988, there has been a dramatic growth in participant direction. Of the plans that were started prior to 1988, the percentage that was participant directed grew from 15 to 83 percent between 1988 and 2005. For plans that were started after 1988, the percentage participant directed grew from 16 to 90 percent. Hence, while start-ups are part of the explanation for the growing share of plans that are participant directed, much of the growth is due to older plans switching to participant direction.

Figure 4 presents a slightly different perspective on the issue of how start-ups affect the degree of participant direction. It shows the trend in participant direction according to whether the plan was started prior to 1988, or whether it is a startup plan in a given year. The difference between this and figure 4 is that start-up plans will appear in the data only in the year that they start up, whereas in figure 4, a plan started after 1988 appears in the data every year after it starts. Figure 4 makes it clear that start-up plans were only slightly more likely than older plans to be participant directed in any given year. Moreover, there was a pronounced increase in the probability that a start-up plan would begin with participant direction since 1990. Consequently, there is compelling evidence that the growth in participant direction since 1990 was the result of two factors: (1) old plans were switching to participant direction; and (2) start up plans became more likely to start as a participant directed plan. 


\section{Empirical Analysis}

In this section, we examine how pension plan features and worker characteristics influence the chance that an ongoing plan switches to participant direction, and the chance that a start up plan begins with participant direction. Because large plans (100 or more participants) are sampled annually and provide more information on assets, income and expenses than small plans, our analysis is based upon the large plans. While restricting analysis to the large plans could bias our conclusions, it is worth noting that the shift to participant direction has been similar in both the small and large plans, though large plans are slightly more likely to be participant directed (see figure 5).

To investigate what determines the chance that on-going pension plans switch to participant direction, we estimate a hazard model. In our analysis, the hazard rate represents the probability of switching to participant direction conditional upon being a centrally managed fund in the prior year. To examine the determinants of the hazard rate, we estimate a Cox proportional hazards model which assumes that the hazard rate of switching plan i to participant direction in period $t$ is

$$
h_{i t}=h_{0 t} \exp \left(X_{i t} \beta\right)
$$

where $h_{i t}$ is the hazard rate, $h_{0 t}$ is the baseline hazard for all plans in period $t$, and $\mathrm{X}_{\mathrm{it}}$ is a vector of characteristics describing plan i in period t. We measure all the control variables as deviations from means so that the baseline hazard rate can be considered as an estimate of the hazard rate for the average pension plan in the sample. ${ }^{7}$ This specification allows the

\footnotetext{
${ }^{7}$ Since the hazard rate is $h_{i t}=h_{0 t} \exp \left(X_{i t} \beta\right)$ where $\mathrm{h}_{0 \mathrm{t}}$ is the baseline hazard, if $\mathrm{X}_{\mathrm{it}}$ is measured as a deviation from mean, $h_{i t}=h_{0 t}$ because $\bar{X}_{i t}=0$ and $\exp \left(\bar{X}_{i t} \beta\right)=1$.
} 
characteristics $\mathrm{X}$ to shift the hazard rate for a given pension plan up or down relative to the baseline hazard rate depending upon whether $\beta$ is positive or negative.

Table 1 summarizes the means of the control variables included in our analysis. The plan characteristics are drawn from the Form 5500 data. Since the Form 5500 provides limited information about the plan participants, we estimate the average level of education and real income for pension-eligible private sector workers at firms with 100 or more workers in each 3digit industry using data from the March Current Population Surveys between 1989 and 2002.

In addition to worker characteristics, our analysis controls for several plan characteristics that could influence the likelihood of switching to participant direction. For example, we expect that when employees contribute a larger share of the funds into the pension plan that they would be more likely to pressure the employer to give them control of the funds. Working in the opposite direction, when employers want their workers to invest in the company stock, we expect that the employer will be less willing to allow a switch to participant direction since the workers may divest themselves of the stock.

Collective bargaining could affect the demand for participant direction in a few ways. First, as noted by Freeman and Medoff (1984), unionization places greater weight on the "median" than the "marginal" worker in the determination of compensation, resulting in the compensation package being tilted towards the preferences of senior workers. It is unclear, however, how this would alter worker demand for participant direction. Collective bargaining might also create "voice" effects whereby the pension fund would have better information on the preferences of the workers in terms of asset allocation, thus reducing the demand for participant direction. Finally, collective bargaining could proxy for worker characteristics in terms of their 
financial sophistication. Unionized workers, on average, are less educated and this could lower demand for participant direction. ${ }^{8}$

A pension plan that is performing poorly relative to the rest of the market could cause workers to pressure for control over the assets. To control for this, we include the difference between the plan's rate of return in a given year and the average return earned by all DC plans in the same year. The pension's annual rate of return is estimated using the approach described in McCarthy and Turner (1989).

Factors influencing switch to participant direction.

Figure 6 presents the baseline hazard rate for 1991 through 2005. Over the 15 year period, the average hazard rate for a switch to participant direction is $8.3 \%$. There is a significant spike in the hazard rate in 1999 where it peaks at approximately 16 percent. This spike could be the result of two phenomena. First, as described earlier in our description of the data, the question about participant direction was changed on the Form 5500 in 1999. This change in the question could have contributed to the spike since prior to 1999, it is unclear how plans where participants controlled some (but not all) of the assets self-reported their participant direction status. After 1999, plans are specifically asked whether participants control none, some, or all of the assets. We count any plan where participants control at least some of the assets as participant directed.

\footnotetext{
${ }^{8}$ As an example, our own analysis of the April 1993 Current Population Survey data reveals that, among workers with a DC plan, the percentage with at least a college degree is much lower among unionized workers (13.5 versus 33.6 percent).
} 
The other major factor that could contribute to the spike in 1999 is that this is the first year that the Form 5500 data was entered using electronic scanning. There is anecdotal evidence suggesting that the first attempt at electronic scanning may have led to more "noise” in the 1999 data, and our own analysis of the data supports that conclusion. We cleaned the data on participant direction status by requiring that a plan be participant directed for two consecutive periods as a check of whether it was a true switch or simply noise. The baseline hazard rate and estimated coefficients are based upon the “cleaned” data.

In the first column of table 2, we present estimates of the hazard model for switching to participant direction. The control variables explaining a switch toward participant direction are based upon the previous period's values. For example, the hazard rate for a switch between 1990 and 1991 is modeled as a function of the plan characteristics in 1990. A given coefficient reveals the percentage effect of a one-unit change in the control variable on the pension plan's hazard rate relative to the baseline hazard. For example, a coefficient of .1 on a variable implies that a one unit increase in the variable increases the hazard rate by 10 percent of the baseline hazard.

The hazard model estimates reveal several important determinants of whether a plan switches to participant direction. First, plans that underperform relative to the market in the previous year are more likely to switch to participant direction. If underperformance relative to the market increases by 10 percentage points, the hazard rate of switching to participant direction increases by 5.4 percent. $^{9}$

\footnotetext{
${ }^{9}$ Evaluated at the sample mean, the average hazard rate over the period is .083. Consequently, a 5.4 percent increase in the hazard rate implies that the hazard rate for a plan with the average characteristics increases by 0.45 percentage points.
} 
Not surprisingly, investments in employer securities substantially reduce the chance of a switch to participant direction. A 10 percentage point increase in the share of assets invested in employer stock reduces the hazard rate of a switch to participant direction by 13.9 percent.

The size of the plan has negligible and statistically insignificant effects on the probability of switching to participant direction. Per capita assets also have no statistically significant effect. Consequently, it does not appear as though scale economies in the administration of individual accounts are sufficient to have much of an influence on the decision to switch to participant direction - at least among plans with 100 or more participants.

A collectively bargained plan is 40 percent less likely to switch to participant direction. As discussed earlier, unions could affect the demand for participant direction in several different ways, and we are not able to distinguish between the competing explanations here. Nevertheless, it is clear that collectively bargained plans are much less likely to give control of the pension assets to the workers.

We also examine a start-up plan's decision of whether to offer participant direction. There are nearly 37,000 DC plans that start over the 1988-2005 time period. As noted above, the percentage that started with participant direction rose rapidly over time. In the second column of table 2, we present estimates of a probit model of the decision to start with participant direction. The control variables are more limited than in the hazard analysis and represent contemporaneous (not lagged) values. We also include year dummies in the analysis. The reported coefficients represent the marginal effect of a one unit change in the corresponding variables on the probability that participant direction is chosen at start-up. All estimates are evaluated at the sample mean. 
The results are generally consistent with those in the hazard models. For example, plans in industries with a more educated work-force and those with a larger share of contributions coming from the employees are more likely to start as participant directed plans. Also, greater investments in employer securities reduce the chance that a plan chooses participant direction. There are two statistically significant results that conflict with those found in the hazard model estimation. First, increases in real income tend to reduce the probability that a plan starts as a participant directed plan. The magnitude of this effect is quite small in economic terms, however, as the estimates imply that a $\$ 10,000$ increase in average income for workers in the industry reduces the probability that a start up chooses participant direction by only .03. Second, firms with DB plans are less to start plan that is participant directed.

One issue that we have not been able to address is the extent to which clarification of the requirements for satisfying section 404(c) stimulated the growth of participant direction. Unfortunately, Form 5500 did not collect information on whether a plan is filing for 404(c) protection until 1999. Table 3 presents the statistics on 404(c) protection for participant directed plans with 100 or more participant since 1999.

Among large plans, there is a significant fraction of plans that do not have 404(c) protection, though the percent with protection has been rising. In 1999, only 47 percent of participant directed plans had 404(c) protection; by 2005, this had grown to 77 percent of plans. Consequently, it appears that a large number of pension plans were switching to participant direction in the 1990s without 404(c) protection. While clarification of the requirements for 404(c) protection in 1992 may have contributed to the growth of participant direction, it was clearly not the only factor. 
Effects of Participant Direction on Contributions and Asset Management.

The last issue we address is how a switch to participant direction affects contributions to the plan and how assets are managed. Using two cross-sectional data sets, Papke (2003a) estimates that participant direction increases employee contributions by approximately 3 percent of salary. Her paper acknowledges the possibility that participant direction could be endogenous in the contribution equation, but notes the difficulty in finding appropriate instruments. In a subsequent paper, Papke (2003b) uses cross sectional data and specifically addresses the endogeneity issue. Using two-stage least squares to correct for endogeneity of participant direction increases the estimated effect of participant direction on contributions from 3 to 9 percent of salary. The validity of her two-stage approach relies upon the assumption that firm size is an appropriate instrument for participant direction in the contribution equation. Statistical evidence is presented supporting the validity of the instruments.

While two-stage approaches can correct for the potential endogeneity of participant choice, the results can be sensitive to the chosen instruments. An alternative method is to use panel data to difference out any plan specific characteristics that are correlated with both participant direction status and the level of contributions. That is, for example, suppose that greater employee financial sophistication leads to both increased contributions and greater demand for participant direction. If financial sophistication is not controlled for in the contribution regression, the estimated effect of participant direction on contributions will be biased upwards. Panel data allows us to control for fixed effects representing unobserved saving traits of the participants and eliminate any such bias. 
To investigate whether a lack of control for fixed effects biases the conclusions about the effect of a switch to participant direction on several pension outcomes, we present regression estimates with and without plan fixed effects in table 4. The regression models include controls for worker and plan characteristics, but only the coefficient on the participant direction dummy is reported. In every regression estimated, the fixed effects are statistically significant at the .01 level and thus we consider it to be the preferred specification.

The first outcome of interest is the effect of participant direction on the level of contributions. According to the OLS model, participant direction increases per capita employee contributions by $\$ 1,015$. When plan fixed effects are added, the effect drops to $\$ 222$ but remains statistically significant at the .01 level. The fact that the estimated effect of participant direction drops to less than one-fourth of its original value when plan fixed effects are included suggests that the plans with unobserved characteristics associated with greater employee contributions are more likely to adopt participant direction. Such a result seems reasonable if, for example, more financially sophisticated employees are likely to both save more and are more likely to receive control over their pension assets.

While participant direction increases employee contributions, it has a small but statistically significant negative effect on employer contributions. In the model with plan fixed effects, participant direction is estimated to reduce employer contributions by $\$ 33$ per participant. Overall, our estimates suggest that a switch to participant direction would increase total contributions (employer + employee) by $\$ 189$ annually.

Our estimates of the effect of participant direction on contributions are much smaller than those found in earlier work. Since average per capita contributions in our sample are \$2,925, a \$189 increase in contributions represents a 6.5\% increase in contribution levels. On the other 
hand, the estimates in Papke (2003a) suggest that mean contribution levels (as a percentage of salary) would increase by 3.3 percentage points. Since the mean contribution rate in Papke's study is 4.7 percent of salary, her estimates suggest that participant direction would increase contributions over by 70 percent - over ten times our estimated effect from the model with plan fixed effects. On the other hand, if we remove the plan fixed effects, our estimated effects are closer (a 26 percent increase in contributions), but still substantially below her estimates.

There are a few possible explanations for our much smaller effects of participant direction on contributions. First, unlike earlier studies, we have panel data and controlling for plan-level fixed effects significantly reduces the estimated effect of participant direction. A study using cross-sectional data cannot control for plan-level fixed effects and may thus overstate the effect of participant direction on contributions. Second, the estimates could be sensitive to the sample. The cross-sectional data used in Papke (2003a) are from the National Longitudinal Survey of Mature Women and the Health and Retirement Study which include older workers (over 45 in the NLS and 51-61 in the HRS) than in the general population. It is possible that these older workers have greater response elasticities. Also, her data is from the early 1990s when participant direction was just beginning, whereas our data spans 1989 through 2005. Finally, our estimates are based upon plan-level data, whereas she uses individual participant level data.

The remainder of table 4 investigates the effect of participant direction on the type of assets held. It is important to note that the Form 5500 data is not well suited for analyzing how the plan is divided between broad asset categories like stocks and bonds. The reason is that many pension plans use outside asset managers, such as an insurance company, a bank trust, or a registered investment company. Assets in such accounts are not broken down on the Form 5500 
into stocks and bonds. Information on stock and bond holdings is reported only when the assets are managed by the pension plan. The one exception, however, is the employer's own stock. Such asset holdings are usually listed on the Form 5500 as a separate category because they are rarely included in the assets managed by outside contractors. The Form 5500 data also provides good information on whether the money is managed internally, or whether the task is outsourced to an insurance or registered investment company.

The regression analysis of the share of pension assets in the various categories reveals that a switch to participant direction leads to a significant increase in the use of outside asset managers. According to the models with plan fixed effects, participant directed plans have 14 percent more of their assets in trusts, 9 percent more in registered investment companies and 1 percent more in insurance companies. These changes are offset by a reduction in the plan's holdings of stocks and bonds. The fact that pension plans increase their use of these outside asset managers when they switch to participant direction is not surprising. These outside asset managers have the infrastructure necessary to deal with individual account management and daily valuation. There are undoubtedly economies of scale in the administration of such activities, and it is no surprise that pensions attempt to take advantage of such by using outside contractors.

The final outcome we investigate is the impact of a switch to participant direction on investments in employer stock. The model with fixed effects suggests that the share of assets invested in employer stock drops 6.1 percentage points with a switch to participant direction. As noted earlier, this is one reason that firms may be reluctant to switch to participant direction since it may want employees to hold employer stock in their pension for agency reasons. It is worth noting, however, that a firm could still force employees to hold employer stock by giving 
them control over only part of the assets in the pension plan - for example, control over the employee contributions, but not the employer's.

Since 1999, the Form 5500 provides information on whether the pension plan has all or only some of the assets under participant direction. As of 2005, 95 percent of the participant directed plans gave employees control over all the assets in the plan. However, among plans that reported holdings of some employer securities, only 65 percent of plans gave employees control over all assets. Consequently, some employers allow employees to self-direct some of the assets, but simultaneously require that a portion of the plan be held as employer securities.

\section{Summary and Conclusions.}

This paper investigates the dramatic growth in participant direction that has occurred over the past 20 years. We find that several factors influence the chance that an ongoing plan or a start-up will give control over the assets to the employees. First, when the plan is underperforming relative to the market, an on-going plan is more likely to switch to participant direction. Second, as the employees’ share of total contributions increases, existing plans are more likely to switch to participant direction and start-up plans are more likely to choose participant direction at start-up. We also find evidence that when the pension is collectively bargained or has greater investments in employer stock, the pension is less likely to give control to the participants.

Some have suggested that the clarification of requirements for satisfying section 404(c) may be largely responsible for the growth in participant direction. While it undoubtedly played a role, we find nearly one-half of large participant directed plans in 1999 did not seek 404(c) 
protection. Consequently, factors other than 404(c) must have played an important role in the transition to participant direction. We believe that the improved technology suited for administering individual accounts and the rapid growth of the mutual fund industry facilitated the growth. We admit, however, that we are unable to quantify the effects of these changes on the growth of participant direction.

When a plan switches to participant direction, employees increase their contributions. However, we find much smaller effects than earlier studies, perhaps because we are able to control for plan level heterogeneity of employees using panel data. We also find that a switch to participant direction causes a shift out of employer securities, though employers might try to prevent a flight from their securities by giving employees only partial control of assets.

In conclusion, the switch to participant direction over the past 20 years has been dramatic and we have presented some evidence on its causes and consequences. An important question which remains unanswered is what the long run consequences of this change will be for retirement income adequacy. That is, for example, will this shift in the responsibility for managing the assets lead to greater pension wealth at retirement. The answer to this depends upon how well participants manage the assets and the effect of the shift to individual accounts on the overall return on pension assets. 


\section{References.}

Agnew, Julie. "Inefficient Choices in 401(k) Plans: Evidence from Individual Level Data." College of William and Mary Working Paper, 2002.

Ameriks, John, and Zeldes, Stephen P. “How Do Household Portfolio Shares Vary With Age?” Working Paper, Columbia University, December 2001.

Benartzi, Shlomo. "Excessive Extrapolation and the Allocation of 401(k) Accounts to Company Stock.” Journal of Finance 56 (October 2001): 1747-1764. ., and Thaler, Richard H. "Naive Diversification Strategies in Defined Contribution Savings Plans.” American Economic Review 91 (March 2001): 7998.

Brown, Jeffrey R.; Liang, Nellie; and Weisbenner, Scott. “401(k) Matching Contributions in Company Stock: Costs and Benefits for Firms and Workers.” Journal of Public Economics 90, August 2006: 1315-1346.

Elswick, Jill. “More Unions are Adopting Self-Directed Plans.” Employee Benefit News, June, 2002.

Freeman, Richard and Medoff, James. What Do Unions Do? New York: Basic Books. 1984

Huberman, Gur and Jang, Wei. "The 1/N Heuristic in 401(k) Plans." Finance and Economics Working Paper, Columbia University, April 2004.

Kaplan, Robert M. “The Times They Are a Changin’ (Maybe)” Journal of Pension Benefits: Issues in Administration, Winter 2003, Vol. 10(2), p87-90.

Liang, Nellie, and Weisbenner, Scott. "Investor Behavior and the Purchase of Company Stock in 401(k) Plans - The Importance of Plan Design.” NBER Working Paper No. 9131. Cambridge, MA: National Bureau of Economic Research, August 2002.

McCarthy, David D., and Turner, John A. "Pension Rates of Return in Large and Small Plans." In Trends in Pensions, edited by John A. Turner and Daniel J. Beller. Washington, D.C.: U.S. Department of Labor, Pension and Welfare Benefits Administration, 1989, pp. 235-286.

Page, Ben. “Administrative Costs of Private Accounts in Social Security,” Congressional Budget Office Report, March 2004. 
Papke, Leslie E. "How Are Participants Investing Their Accounts in Participant-Directed Individual Account Pension Plans?” American Economic Review 88 (May 1998): 21216. - “Individual Financial Decisions in Retirement Saving Plans: The Role of Participant-Direction.” Journal of Public Economics 88 (January 2003a): 39-61.

. "Choice and Other Determinants of Employee Contributions to Defined Contribution Plans.” Social Security Bulletin 65 (Issue 2 2003b): 59-68.

Samuelson, William, and Zeckhauser, Richard. “Status Quo Bias in Decision Making,” Journal of Risk and Uncertainty 1 (March 1988): 7-59.

Sengmuller, Paul. "Performance Predicts Asset Allocation: Company Stock in 401(k) Plans.” Columbia University, Department of Economics. April 2002.

Weisbenner, Scott. "Do pension plans with participant investment choice teach households to hold more equity?” Journal of Pension Economics and Finance, November 2002 1(3) : 223-248. 
Figure 1

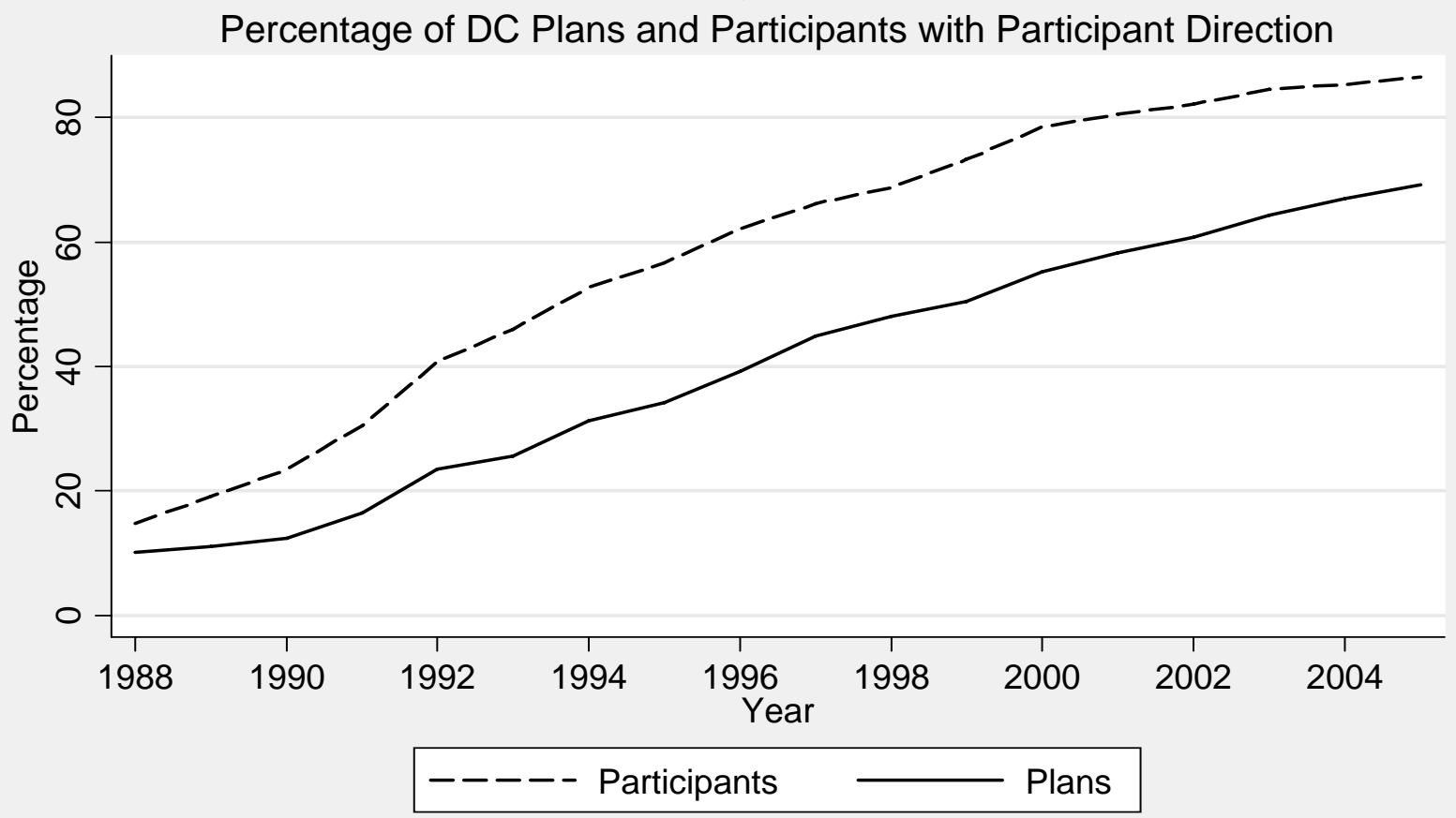

Authors ' calculations based upon IRS Form 5500 filings by defined contribution plans

Figure 2

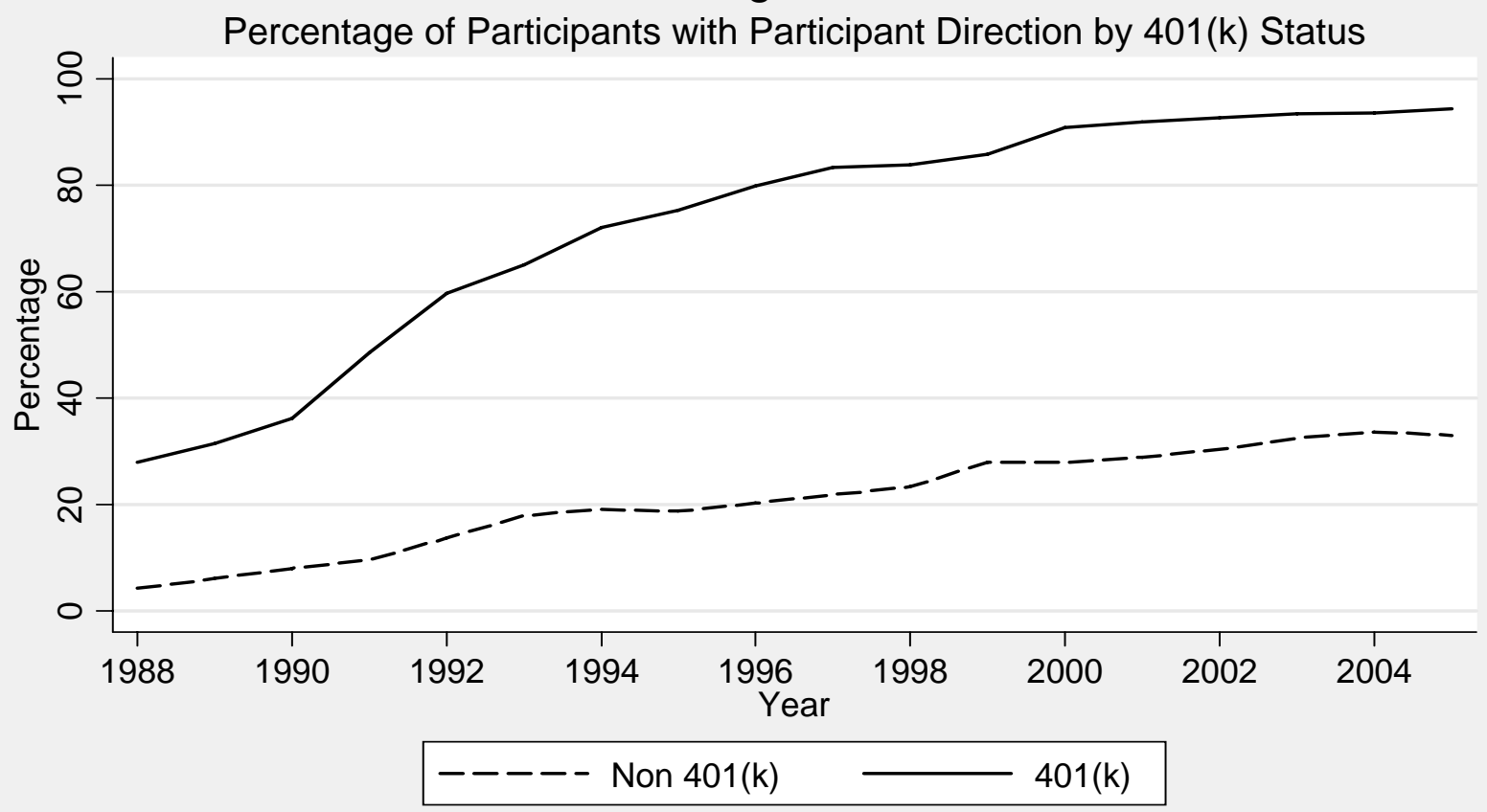

Authors ' calculations based upon IRS Form 5500 filings by defined contribution plans 
Figure 3

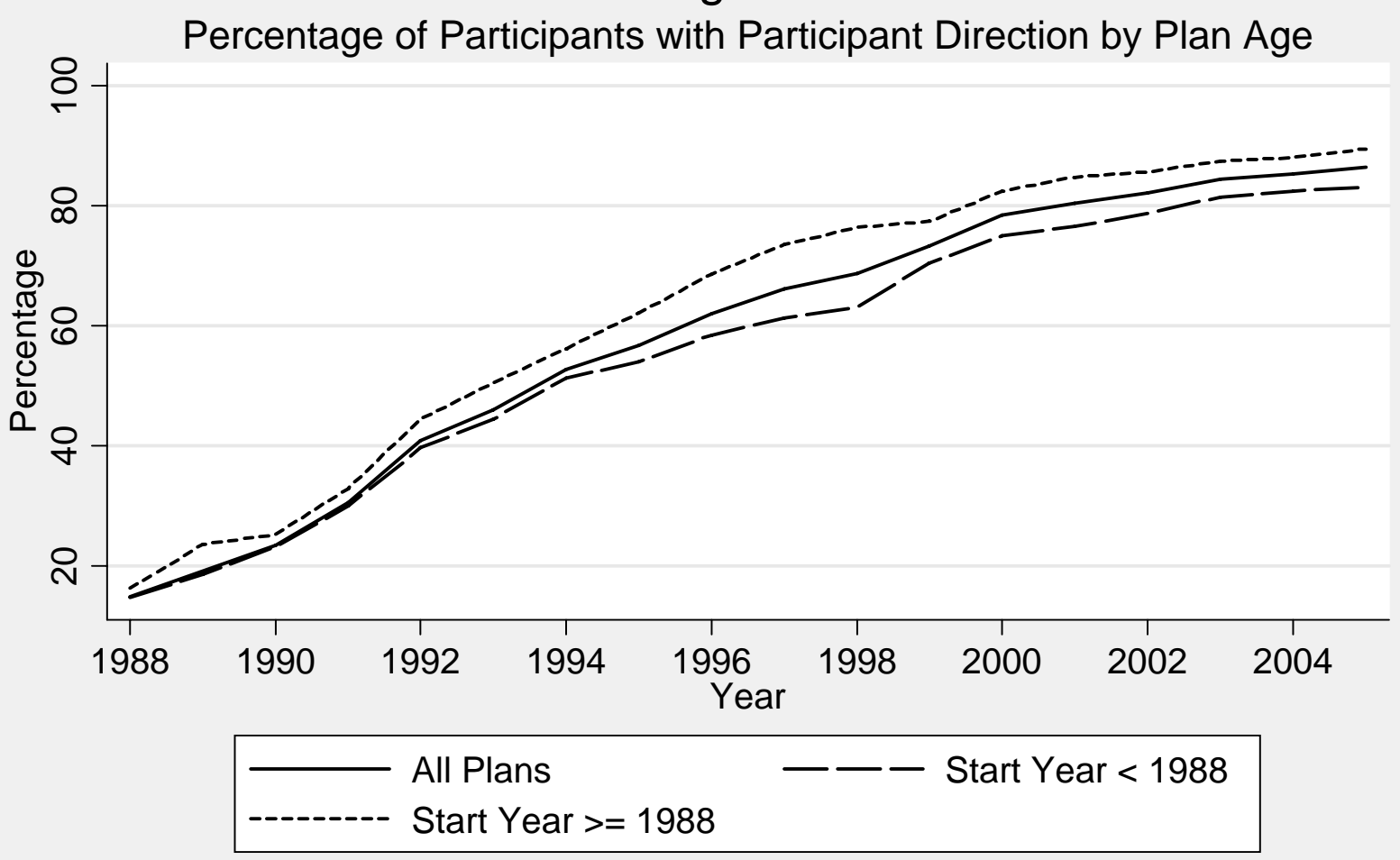

Authors ' calculations based upon IRS Form 5500 filings by defined contribution plans

Figure 4

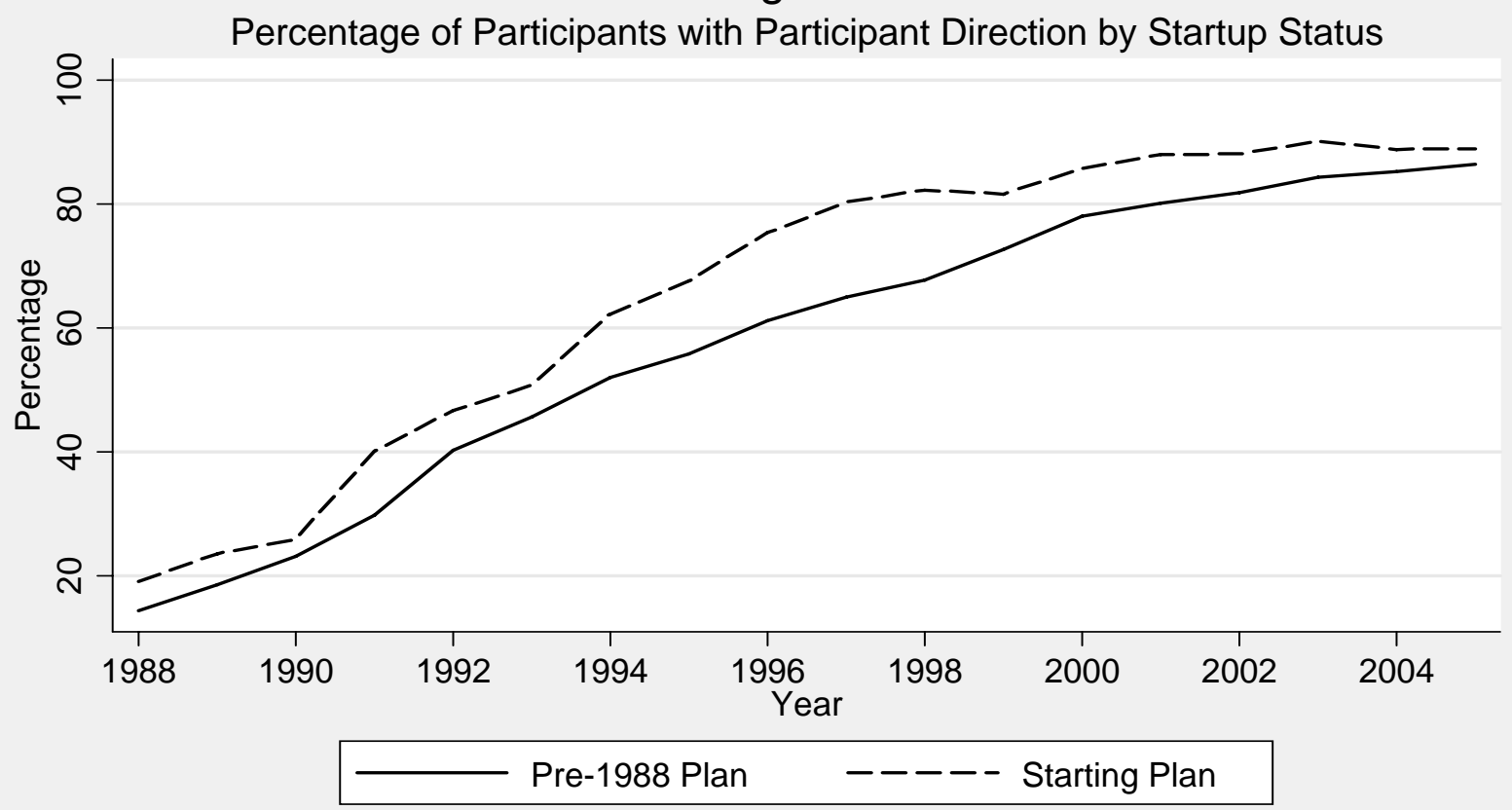

Authors ' calculations based upon IRS Form 5500 filings by defined contribution plans 
Figure 5

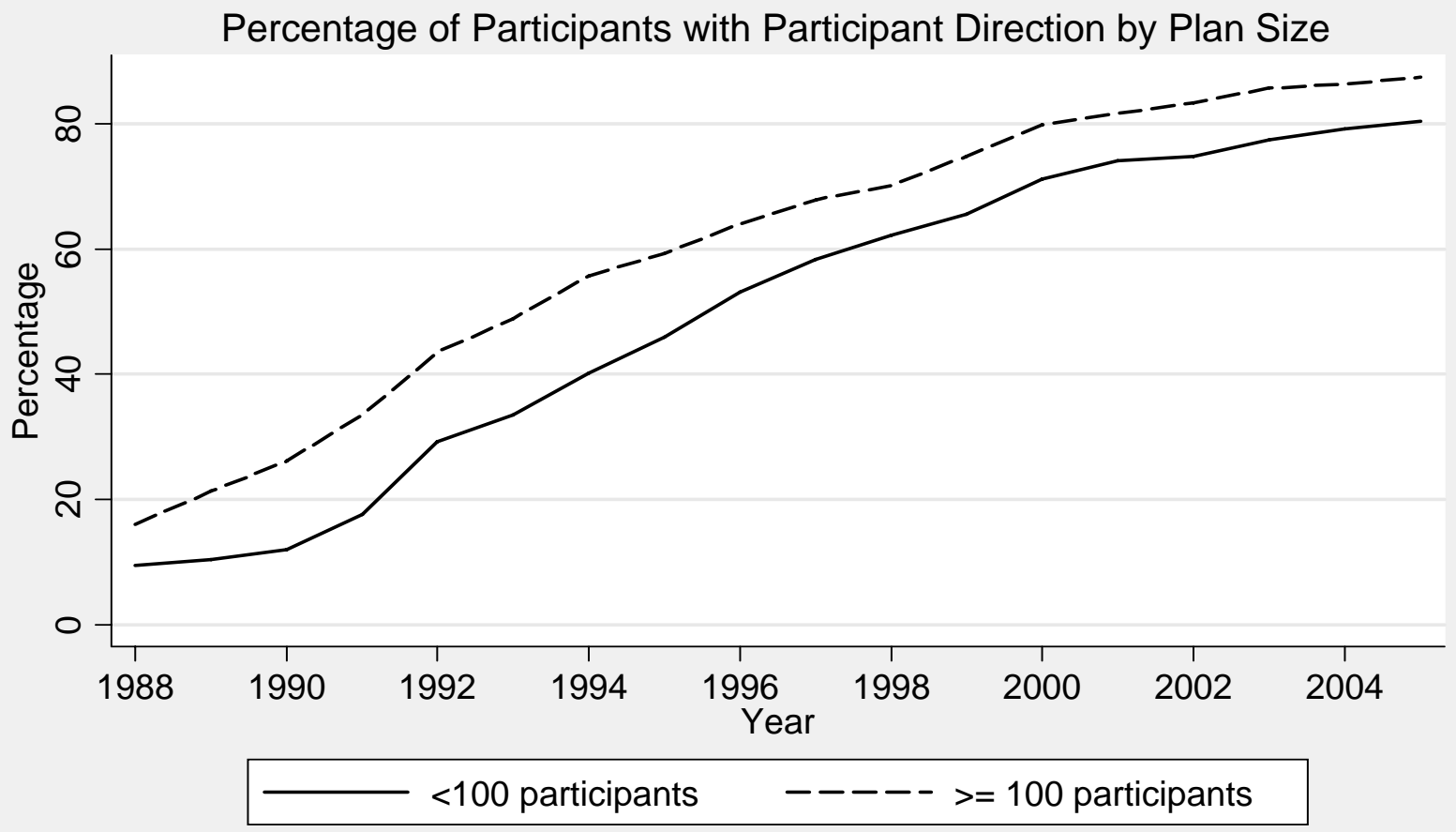

Authors ' calculations based upon IRS Form 5500 filings by defined contribution plans

Figure 6

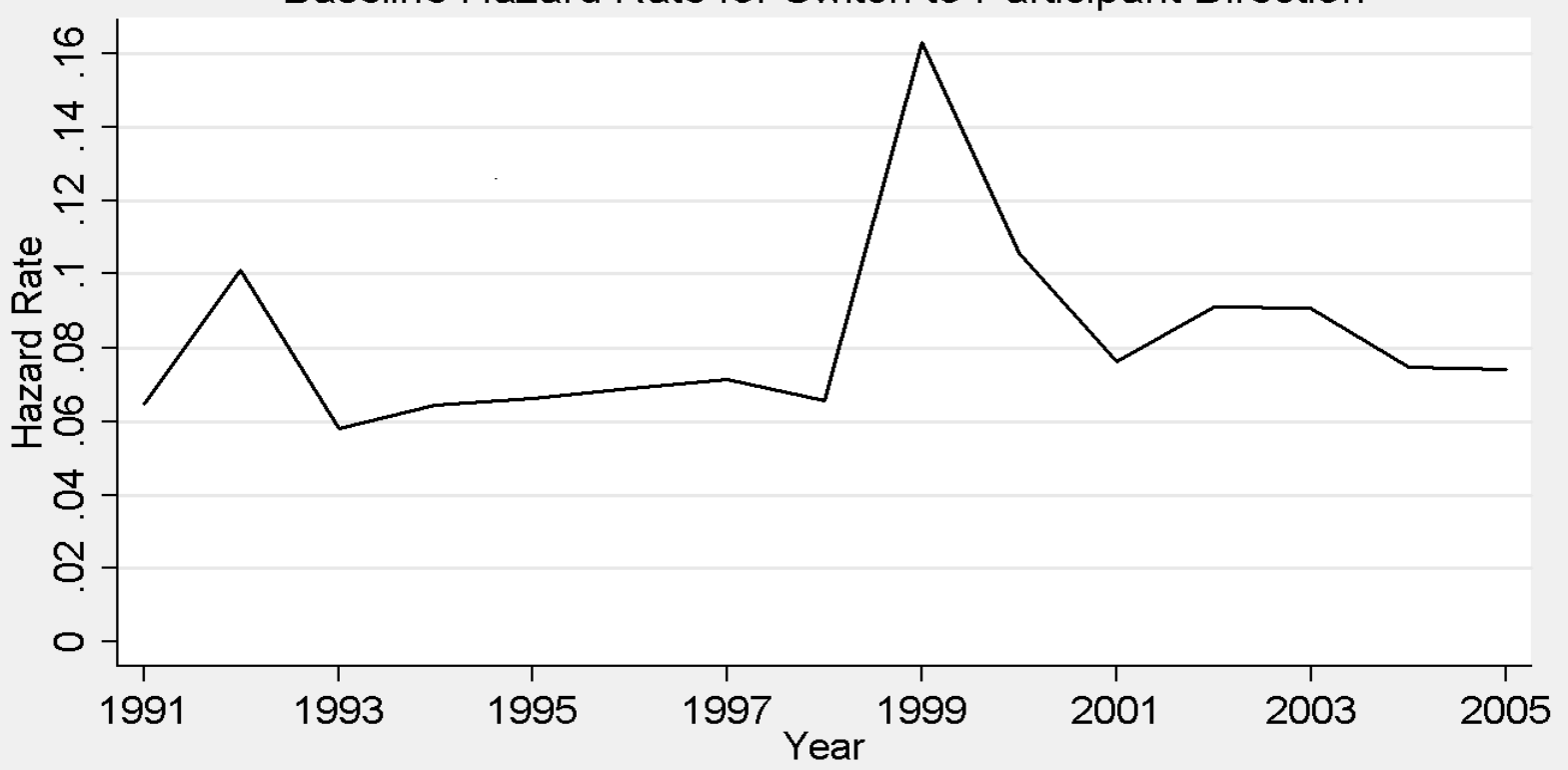

Note: The baseline hazard is estimated from a Cox proportional hazards model and represents the hazard rate for a plan with characteristics equal to the sample mean. The hazard rate in year $t$ is the hazard for switching to participant direction between year $(t-1)$ and $t$. In 1999 , there was a change in the question to determine participant direction status (see text for details.) 
Table 1. Sample Means for Form 5500 Data Used in Hazard Estimation.

Deviation from Mean Rate of Return

Plan Age (in years)

\% of Assets in Employer Securities

\% 401(k) Plan

Real Wage Income (in 1000s of \$2003)

Years of School

Per-capita Assets (in 1000s of \$2003)

Employee's Share of Contributions

Union Plan

Firm Also Offers a DB plan

Number of Participants

\# of observations

\# of plans
0.002

15.58

$10.6 \%$

$43.1 \%$

41.9

13.4

25.4

$29.7 \%$

$10.9 \%$

$20.9 \%$

1,027

156,480

43,320 


\section{Table 2. Factors Influencing the Participant Direction among Ongoing and Start-up Plans.}

\begin{tabular}{|c|c|c|}
\hline Variable & $\begin{array}{l}\text { Determinants of Hazard Rate of } \\
\text { Switching to Participant Direction }\end{array}$ & $\begin{array}{l}\text { Probit Estimates of } \\
\text { Determinants of } \\
\text { Participant Direction for } \\
\text { Starting Plans }\end{array}$ \\
\hline \multirow[t]{2}{*}{ Deviation From Mean Rate of Return } & $-0.542 * * *$ & -- \\
\hline & $(-6.36)$ & \\
\hline \multirow[t]{2}{*}{ Plan Age } & $-0.0250 * * *$ & -- \\
\hline & $(-13.0)$ & \\
\hline \multirow[t]{2}{*}{$(\text { Plan Age })^{2}$} & $0.000323 * * *$ & -- \\
\hline & $(11.4)$ & \\
\hline \multirow[t]{2}{*}{ \% of Assets in Employer Securities } & $-1.394 * * *$ & $-0.429 * * *$ \\
\hline & $(-10.8)$ & $(-17.2)$ \\
\hline \multirow[t]{2}{*}{ 401k Plan } & $0.848 * * *$ & $0.312 * * *$ \\
\hline & (20.9) & $(33.5)$ \\
\hline \multirow[t]{2}{*}{ Real Income (in 1000s of 2003\$) } & 0.00178 & $-0.00251 * * *$ \\
\hline & $(0.90)$ & $(-8.69)$ \\
\hline \multirow[t]{2}{*}{ Years of School } & $0.0694 * * *$ & $0.0573 * * *$ \\
\hline & $(2.74)$ & $(15.0)$ \\
\hline \multirow[t]{2}{*}{ Per capita Assets (in 1000s) } & -0.00265 & -0.0000200 \\
\hline & $(-0.059)$ & $(-1.34)$ \\
\hline \multirow[t]{2}{*}{ Employee Share of Contributions } & $0.268 * * *$ & $0.332 * * *$ \\
\hline & $(8.00)$ & $(41.8)$ \\
\hline \multirow[t]{2}{*}{ Union Plan } & $-0.405 * * *$ & -0.00824 \\
\hline & $(-4.28)$ & $(-0.84)$ \\
\hline \multirow[t]{2}{*}{ Employer Offers DB plan } & $0.0877 * * *$ & $-0.125^{* * *}$ \\
\hline & $(2.85)$ & $(-18.1)$ \\
\hline \multirow[t]{2}{*}{ 1000s of Participants } & 0.00242 & $0.00372 * * *$ \\
\hline & $(0.77)$ & $(2.59)$ \\
\hline \multirow[t]{2}{*}{$\left(1000\right.$ s of Participants) ${ }^{2}$} & -0.000008 & -0.00000660 \\
\hline & $(-0.78)$ & $(-1.31)$ \\
\hline Sample Size & 156,480 & 36,977 \\
\hline
\end{tabular}

Note: $* * *$ indicates significance at the .01 ;** at the .05 and * at the 0.1 level. The probit model also includes year dummies. 
Table 3. Percentage of Plans with 404(c) Protection. ${ }^{\text {a }}$

\begin{tabular}{cc}
\hline Year & Percent with $404(\mathrm{c})$ Protection \\
1999 & $47.9 \%$ \\
2000 & $56.5 \%$ \\
2001 & $61.2 \%$ \\
2002 & $66.9 \%$ \\
2003 & $70.4 \%$ \\
2004 & $74.0 \%$ \\
2005 & $76.6 \%$ \\
\hline
\end{tabular}


Table 4. Effect of Participant Direction on Contributions and Asset Management. ${ }^{\text {a }}$

\begin{tabular}{|c|c|c|c|c|}
\hline \multirow[b]{2}{*}{ Dependent Variable } & \multicolumn{2}{|c|}{$\begin{array}{l}\text { Estimated Effect of } \\
\text { Participant Direction }\end{array}$} & \multicolumn{2}{|c|}{ Sample Size } \\
\hline & $\begin{array}{l}\text { Without Plan } \\
\text { Fixed Effects }\end{array}$ & $\begin{array}{l}\text { With Plan } \\
\text { Fixed Effects }\end{array}$ & $\begin{array}{l}\text { Number } \\
\text { of plans }\end{array}$ & $\begin{array}{l}\text { Number of } \\
\text { observations }\end{array}$ \\
\hline Per capita employee contributions ${ }^{b}$ & $\begin{array}{l}1015 \\
(241)\end{array}$ & $\begin{array}{l}222.4 \\
(59.8)\end{array}$ & 138,764 & 715,215 \\
\hline Per capita employer contributions ${ }^{\mathrm{b}}$ & $\begin{array}{l}-264.2 \\
(60.8)\end{array}$ & $\begin{array}{l}-33.3 \\
(8.03)\end{array}$ & 138,764 & 715,215 \\
\hline Share of assets in trusts & $\begin{array}{l}0.314 \\
(316)\end{array}$ & $\begin{array}{l}0.138 \\
(98.9)\end{array}$ & 140,989 & 735,243 \\
\hline $\begin{array}{l}\text { Share of assets in insurance } \\
\text { companies }\end{array}$ & $\begin{array}{l}0.0424 \\
(79.2)\end{array}$ & $\begin{array}{c}0.0132 \\
(15.9)\end{array}$ & 140,989 & 735,243 \\
\hline $\begin{array}{l}\text { Share of assets in Registered } \\
\text { Investment Companies }\end{array}$ & $\begin{array}{l}0.155 \\
(148)\end{array}$ & $\begin{array}{l}0.093 \\
(67.2)\end{array}$ & 140,989 & 735,243 \\
\hline Share of assets in employer stock ${ }^{\mathrm{c}}$ & $\begin{array}{l}-0.423 \\
(-180)\end{array}$ & $\begin{array}{l}-0.061 \\
(23.9)\end{array}$ & 13,865 & 99,272 \\
\hline \multicolumn{5}{|c|}{$\begin{array}{l}\text { a The reported coefficients are from a regression of the various dependent variables on a participant direction } \\
\text { dummy. Each regression also includes controls for the age of the plan, whether the plan is unionized, number of } \\
\text { participants, industry specific measures of real income and education, and whether the firm also offers a defined } \\
\text { benefit plan. Sample restricted to large plans ( } 100+\text { participants). T-statistics are in parentheses. } \\
\text { b Measured in } 2003 \text { dollars. Sample excludes plans in the top and bottom one percent of employer and employee } \\
\text { per capita contributions and those missing information necessary to derive employee share of contributions. } \\
\text { c Sample restricted to plans that had nonzero holdings of employer stock in at least one sample year. } \\
\text { d The plan fixed effects are statistically significant at the } .01 \text { level in all specifications presented. }\end{array}$} \\
\hline
\end{tabular}

